\title{
A Strategic Political-Culture Basis for Developing the Socioeconomic Welfare of Disadvantaged Urban Communities: General Review and Policy Framework
}

\author{
Yitzhak Dahan ${ }^{1}$ \\ ${ }^{1}$ Division of Public Administration \& Policy, School of Political Science, University of Haifa, Mount Carmel, Haifa, \\ Israel \\ Correspondence: Yitzhak Dahan, School of Political Science, University of Haifa, Mount Carmel, Haifa, Israel.
}

Received: July 21, 2017

doi:10.11114/ijsss.v5i9.2610
Accepted: August 17, $2017 \quad$ Available online: August 21, 2017

URL: https://doi.org/10.11114/ijsss.v5i9.2610

\begin{abstract}
The goal of promoting the economy and social welfare of disadvantaged urban communities has always been at the forefront of community studies; yet, this issue has also remained consistently controversial. The resurgence of the political-culture approach in the urban subfield has shed new light on this matter, raising new insights and presenting novel conclusions. The current study summarizes the main propositions of this approach with regard to community development, and highlights its powerful impact and valuable contribution to the understanding of the construction of urban economy, particularly concerning the welfare of disad vantaged communities. This study supports the application of the political-culture approach by reviewing and discussing major studies that have specifically examined various modes of "social capital" as a moderating concept between economic logic and local political culture (e.g., trust, social cohesion and civic engagement). Analyses of such relationships illustrate the common failure inherent in universal, culturally-blind policymaking, and highlight the importance of integrating the input of political-culture knowledge into the policy-making processes. Given this theoretical base, this paper presents a more effective methodological framework for addressing policy goals, based on the redefinition of the policy problem and a reformulation of policy plans - regarding strategy, institutions, and coalition-building - in accordance with local political-culture features and specific circumstances.
\end{abstract}

Keywords: urban political culture, social capital, urban policy, urban welfare, humanism vs. structuralism

\section{Introduction: Economy, Power, Cul ture and Welfare}

Understanding urban economy, with its naturally wide implications on community social welfare and class affiliation, has always been at the forefront of urban research. However, while economic issues generally have an objective, "scientific" appeal, in practice, the discipline remains debatable and controversial. Taking a broad view, this controversy is not just a matter of different methodologies or political views; rather, it stems from a deep epistemological and philosophical base regarding the very nature of power, economy, and culture.

As a basis for this discussion, one may draw a general, theoretical line separating two major approaches regarding urban economy, as well as urban sociology. The first approach is a structural-universal approach, which considers and emphasizes objective, universal conditions and mechanisms - mainly at the macro level — as being the main sources of the economic qualities of cities. Several classic studies fall into this first category: the ecological school (Burgess, 1961), the Marxists (Harvey, 1973 \& Castells, 1977) and recent political economists (Stone, 1989, 1993, Savitch et al., 2002). Although there are initial fundamental differences between them, they all rest on common ground: that of hard, objective conditions (usually exogenous to the city's residents): such as geographical location, class status, division of political power, ethnicity, globalization, all of which shape community welfare and wellbeing in one way or another. This type of analysis leaves little room for local culture, assuming it to be a secondary, parochial, or residual matter (see: Lane, 1992; Logan \& Molotch, 2007).

Since the late 1980s, structural-universal approaches have been increasingly criticized and debated by political-culture scholars (Wildavski, 1987, Thompson et al., 1990, Lane, 1992, Porter, 2000, Grondona, 2000, Landes, 2000, Sachs, 2000, Reese \& Cox, 2007, Rosdil, 2010, 2011, Woolcock, 2001, Woolcock et al., 2010, \& Grodach, 2012). In essence, these 
recent studies stress that each community's political culture must be taken as a significant source that potentially shapes urban economy and social order. For the purpose of this discussion, "political culture" is defined as "the normative context" within which politicians, as well as community and city residents, function (Reese \& Rosenfeld, 2008:248). This context includes "ideals, beliefs, values, symbols, stories, and public rituals that bind people together and direct them in common action" (Ibid, 248).

Scholars who draw from this theoretical base agree that the abstract qualities of a given society (e.g., values, motivation, human capital, and social capital) have an essential impact on various aspects of urban economy (e.g., markets, consumption, employment, and real estate). According to this line of thought, these qualities cannot be defined merely as reflections of the socioeconomic super-structure, as argued by Marxists and neo-Marxists, nor can they be defined as a system shaped solely by the self-interest of certain groups or individuals, as claimed by the political-economy approach. Instead, the aforementioned qualities should be viewed as a relatively independent variable derived from a source much deeper than universal-rational logic and interests - that of humanistic-culture.

Generally speaking, the difference between the structural-universal and political culture approaches stem from their different epistemological bases, going back to the old, classic debate regarding the very nature of the relationship between politics and social construction, often correlated with realism versus idealism or structuralism versus humanism (Giddens, 1984 \& Almond, 1990). The structural-universal approaches are more likely to lean on realistic and rationalistic bases, assuming that the nature of economy and community welfare is shaped by wider systems, shaped mainly by human needs and interests. In contrast, the political-culture approach tends to moderate this hard logic by arguing that the wider "objective" system should be analyzed in light of the particular set of values, preconceptions, beliefs, cosmology, and norms through which these "needs" and "interests" are actually viewed and interpreted. Herein lies the crucial difference: while a structural-universal approach sets aside the particular cultural knowledge base, assuming a sharp distinction between the social sciences and the humanities, the political-culture approach refutes this separation, a position that holds far-reaching implications when it comes to economic analysis and policy making. Wildavski (1987) criticized political economists who assume cultural and human preferences are "exogenous [and] external to the system being considered" (Wildavski, 1987:4). Even when economic experts rationalize a certain position by claiming "objective considerations," followers of political culture tend to doubt such rationalizations. Grodach (2012) argues that economic considerations never appear in their pure forms, but are rather bound (often subconsciously) with economic imagery; that is, "the specific discourses, symbols and practices that actors rely on to legitimize a given institutional order and to organize against competing imaginaries" (Grodach 2012:83).

Given this inherent relationship, scholars who draw from the political-culture approach argue that achieving a comprehensive understanding of contemporary economy, more specifically the dynamics of urban economic development, cannot be satisfied by only applying formal, mathematical or functional principles or models, such as economy of scales, trickle down, market failure, growth poles and cost-benefit considerations. Rather, they should examine how those principles relate to the local cultural base. As Clark put it: "We need to dig deeper into consumption behavior and interpret its moral, cultural and political meanings" (Clark, 2004, quoted in Horrigmo, 2012:6). A methodology that moves towards "digging deeper" holds, at least theoretically, significant added value. It provides a broader understanding of economic constructs, which, in turn, enable the practical construction of an effective and sustainable policy program.

In light of these propositions, the main argument that guides this study is that an effective way to advance urban policy, which aims to improve the economy and welfare of disadvantaged urban communities, is one that must take into account the political-culture characteristics of the communities under consideration. To do so, policy makers, as well as researchers, must synchronize the universal-rational principles, upon which urban economic development and policymaking rest, with the political-culture system of knowledge that is innate and local-particular, and therefore cannot be understood from a pure rational/logical perspective.

\section{The Urban Arena: Political Culture, Social Capital, and the Reconstruction of Community Welfare}

The rising trend of culture-based studies is clearly reflected in the urban subfield (Putnam, 1993, 2000; Fukuyama, 2000, Bockmeyer, 2000, Middleton et al., 2005, Easterly et al., 2006, Logan \& Molotch, 2007, Andrews, 2009, Quentin et al., 2010, Rosdill, 2010 \& 2011, Grodach, 2012 \& Buchbinder et al., 2015). These studies share the common argument that the best way to understand local economy is by observing the political culture of urban communities that embody those abstract resources that translate into economic values (e.g., exchange value, potential growth, employment structure, poverty, etc.).

The notion that urban economy is significantly shaped by culture is not a trivial matter. Typically, the urban arena is more likely to be perceived as distinct, rigid, and objective, having nothing to do with values or culture. This seemingly appealing view is often supported by scholars following the political-economy approach (Savtich et al., 2002, Stone, 
$1989 \& 1993$ ) who argue that cities were taken over by various interest groups (civilians, entrepreneurs, and politicians) that are mainly concerned with certain "interests" (e.g., real estate, employment, class mobility, improving neighborhood infrastructure - namely issues that are evaluated through uni versal and objective standards). Logan and Molotch (2007) severely criticize this line of thought. In their seminal study Urban Fortune, ${ }^{1}$ they argue that such "interests" and material aspects of city life do not exist in a separate sphere, but rather are intertwined with local culture - a powerful variable that cannot be considered parochial:

The market-driven schools, like ecology, have "left out" human culture. The real flaw of such schools is that they ignore that markets themselves are the result of culture; markets are bound up with human interests in wealth, power, and affection. Markets work through such interests and the institutions that are derived from and sustain them. These human forces organize how markets will work, what prices will be, as well as the behavioral response to prices. (Logan \& Molotch, 2007:9)

Based on this fundamental notion, Logan and Molotch argue that a real understanding of the economic growth of a city should be achieved by examining the relationship between "exchange value" and "use value" as independent variables that at the same time affect each other. As opposed to some conservative approaches, these authors strongly insist that the process of shaping city economy and sociology is heavily affected by the decisions made by politicians who are influenced and manipulated by private interests and entrepreneurs-especially when applying economic-growth strategies - in order to maximize their gains (mainly in real estate). At the same time, Logan and Molotch claim that this mechanism is moderated by "use value" (mainly at the micro-geographical level), such as trust, social networking, local hierarchies, sense of place, and social identity — aspects all best understood by means of socio-cultural analyses.

Aseries of research studies begun in the mid-1990s that aligns with Logan and Molotch's thoughts concentrates on "social capital" as moderating concept at the interface between political culture and urban economy/community welfare.

As an abstract mode of wealth, "social capital" refers to certain qualities of social organization manifested in: social networking, mutuality, civic engagement, and social cohesion-all of which directly or indirectly influence economics, social class, and public welfare (Woolcock, 2001, Putnam, 2000 \& Fukuyama, 2000). Social capital encompasses several forms of social institutions and cultural patterns, with trust being the most important quality.

Putnam (1993) and Fukuyama (2000) argue that economic growth is greater and more sustainable in societies characterized by a high level of mutual trust. Fukuyama stated that truth-telling and the meeting of obligations serve as "a lubricant that makes any group or organization run more efficiently" (Fukuyama, 2000:98). Such virtues avoid the need for inspection, enforcement, and judicial contracts, and thus reduce "transaction costs" (Fukuyama 2000:99).

Trust is also an outcome of social cohesion. Easterly et al., (2006) define "social cohesion" as the nature and extent of social fractionalization and economic division within society. A cohe sive society is one that has fewer potential social fault lines and does not have substantial income inequalities or ethno-linguistic divisions (and is often correlated with societies that share a strong common identity). According to the authors, economic performance will be better in a relatively cohesive society, since there is a greater possibility that people within the same society will work together, especially "when crisis strikes or opportunity knocks" (Easterly et al., 2006:4). Another manifestation of social cohesion may be observed when there is an impending financial crisis. In the case of a non-cohesive society, natural responses may be sluggish, une ven or hysterical (e.g., selling off property - a reaction that often leads to the heightening of other latent

\footnotetext{
${ }^{1}$ Unlike some scholars who mistakenly identify this study with the Political Economy Approach, Urban Fortunes relies on an approach that integrates politics and culture in a non-reductionist manner. Logan and Molotch begin their work by criticizing the common strategy towards urban growth ("the city as a growth machine," pp. 50 -98) where businesses, politicians, and local elites advocate for economic growth by arguing that it would benefit large communities. Often, politicians advocate this strategy by arguing that governmental intervention, through investments in urban infrastructure and subsidizing entrepreneurs, will create a growth dynamic that will inevitably produce some public benefits (e.g., an increase in employment rate, an increase in business activity that will lead to an increase in income, enhanced tax revenue, etc.). However, the inevitable consequences of implementing growth theory, according Logan and Molotch, are an increase in house market values that naturally benefits relatively well affluent groups, which unsurprisingly support this strategy and join the ethos of growth $(50-98)$. At first glance, this section in Urban Fortunes supports the Political Economy Approach, as outlined by C. Stone (1993), who explained urban dynamic as an outcome of economic forces that both shapes and is being shaped by political arrangements. However, this section in Urban Fortunes should be understood as part of a wider thesis. In a broad view, the main focus of Urban Fortunes is the topic of cultural aspects (use value). Essentially, Logan and Molotch reject a common view in urban research that rests on a separation between politics and values. For them, in order to address the classic issue in urban politics of who governs one should first address questions of values and culture.
} 
issues, greater political tension, and sometimes worsens the economic situation). In contrast, in a relatively cohesive society, there is a better chance that individuals may handle such a crisis with more restraint and equanimity, relying on their shared beliefs and values (Easterly et al., 2006).

Civic engagement is also a form of social capital with a clear impact on the local economy, especially on community welfare. Andrews (2009) defines "civic engagement" as political awareness, social activism, and standing up for one's rights. He argued that a high level of civic engagement enables the moderation of "negative externalities for social capital, such as mistrust and lack of respect" (Andrews, 2009:429). Communities that share a low level of civic engagement - that is, communities in which members do not uphold their rights and priorities-are likely to suffer economically. In accordance with Logan and Molotch's aforementioned theoretical framework, a high level of civic engagement may be used as an effective tool to protect the use value, which in turn indirectly protects the exchange value (e.g., residential properties, neighborhood reputation). A well-known example of a society with an extremely low level of civic engagement is in southern Italy, recognized as the poorest region in the western world (Fukuyama, 2000). Scholars who studied this society (Banfield 1967, Putnam, 1993 \& Fukuyama, 2000) have characterized it as founded on a political culture of fatalism and patron-client relationships. According to Putnam (1993), the patron-client pattern is an asymmetrical-hierarchical relationship that is not based on shared values; rather, it rests on the exchange of material resources, inevitably leading to the growing poverty of the local populace.

Nevertheless, "poor communities" do not necessarily represent low levels of social capital. In his seminal study Bowling Alone, Putnam (2001) differentiates two categories of social capital, each drawn from a different cultural basis: "bonding social capital" and "bridging social capital." "Bonding social capital" refers to strong relations among members sharing a similar background (demographic, ethnic, and/or professional), and having a common cultural orientation, which mostly exists in closed societies. In contrast, "bridging social capital" refers to relations between groups having different statuses, often encompassing a myriad of diverse socio-cultural identities. Each type of social capital affects mobility and the achievement of economic gain in a different manner (Putnam, 2001, Middleton et al., 2005 \& Andrews, 2009). Bridging social capital (a concept based on vertical connections) is more likely to improve broadband participation (inclusive), whereas bonding social capital (a horizontal connection) is more likely to stimulate narrowband networks (exclusive), thus limiting the ability to attain external resources and knowledge.

Quentin et al. (2010), who analyzed the relationships between cultural orientations, social capital, and participation in the labor market, support this logic. In their analysis, they argue that the most suitable way to understand structural changes in the labor market and economic difficulties is by focusing on the following questions: How do people manage to cope with those changes? How can people identify opportunities? Indeed, structural changes in labor markets are integrally bound with "geographical labor mobility". However, geographical mobility is not merely an objective, technical operation, but rather a process that is embedded within the socio-cultural system. Accordingly, locally-oriented communities, characterized by close family ties and close friendships (strong bonding social capital, often found in the southern parts of Europe), tend to put constraints on geographical mobility, sometimes even curtailing economic mobility. In such communities, individuals perceive themselves as tied to their local roots; they are often tightly bound to their social capital. This increases the cost of mobility, reduces incentives for migration or emigration, and potentially stymies possibilities for economic upgrading. The opposite conditions hold true in Northern Europe, where social relationships are characterized by a more general type of social capital (namely, bridging social capital) and by higher levels of mobility (Quentin et al., 2010).

Put concisely, the thought process behind these studies is that economics, as well as social class affiliation, is not divorced from culture - especially political culture. Therefore, scholars must take political culture as an independent variable, one that often exists beneath the surface and contains highly-valuable local knowledge: hierarchies, preconceptions, ethics, and aesthetics, all of which have far-reaching implications for policy-making and policy analysis.

\section{Promoting the Socioeconomic Welfare of Disadvantaged Urban Communities: A Strategic Uni versal-Rational Basis versus Political Culture}

The most basic principle derived from the above discussion is that policymakers, who seek to promote the welfare of disadvantaged communities, must take into account the socio-cultural differences between various urban communities when designing local policy reforms. Researchers who follow the political-culture approach (Bockmeyer, 2000, Geva-May, 2002, Easterly et al., 2006; Logan \& Molotch, 2007, Reese \& Rosenfeld, 2008 \& Woolcock et al., 2010) propose that applying a uni versal policy program does not ensure a successful outcome and "may even worsen policy" (Woolcock et al., 2010:16). Woolcock and his associates argue that the common practice of institutions and governments, of exporting and importing cross-culturally or cross-nationally-based policy programs, labeled as "context-free policy science" (2010:12), is inherently misleading and essentially limited, since such programs are "severely handicapped as detailed guides to practical action in any particular context" (ibid., 12). They have shown that similar development 
policies implemented in different regions and communities had different and "unexpected consequences" and produced a "non-linear trajectory" impact (Woolcock et al., 2010:14). Similarly, Logan and Molotch (2007) show that adopting and applying a policy of urban economic growth as a strategy for advancing poor communities (termed "value free development") had a different impact in the various communities, producing different outcomes on the labor market and the reshaping of class and ethnic segregation. In many ways, this is the inevitable consequence of the application of 'culturally-blind' policy programs.

These unexpected policy outcomes resulted from the existence of deeper, hidden distinctions on the level of local culture and local community history. ${ }^{2}$ Thus, researchers who wish to understand the gaps between policy goals and policy outcomes must first trace the cultural and historical roots of the policy object as a means for addressing the following question: How are existing or non-existent resources (material, financial or abstract) being processed and interpreted? The following hypothetical policy outline offers elaboration.

Assume that there is an urban policy program that aims to improve the welfare standards of relatively disadvantaged urban communities in some city by promoting urban economic growth. This policy is promoted by attracting investors to the city by subsidizing entrepreneurs and improving the city's physical infrastructure; these improvements would trickle down to the low-income neighborhoods, such that different communities might utilize the potential gains and economic benefits resulting from expected growth. Yet, given cultural logic, it is possible that various groups, categorized as "disadvantaged," would most likely interpret the new material resources on the basis of their historical backgrounds and cultural preconceptions.

The policy program suggested above would not succeed, for example, in the case of a fatalistic political culture (Wildavski, 1987), ${ }^{3}$ suffering from "horizontal distrust." Policies that assume that community members will take advantage of economic opportunities when they arise are doomed to fail when the community lacks the most basic prerequisites for utilizing opportunities or resources; namely, self-confidence and community trust. As C. A. Bayly articulated: [People] "need to believe that they can succeed and that their own societies are essentially benign" (quoted in: Woolcock et al., 2010:17). An additional condition under which the abo ve policy program might not materialize is in the case of a community characterized by a political culture of vertical distrust towards the establishment and towards its political leadership. Easterly et al., (2006) argued that a policy that aims at generating economic reforms-for example, by striving to advance economic growth and equity - would not achieve its ends if community members distrust the regime or its politics. This is because the enactment of policy requires trust and social cohesion, which are "essential for generating the confidence and patience to implement reforms: citizens have to trust the government that the short-term losses inevitably arising from reform will be more than offset by long term gains" (Easterly et al., 2006:1-2).

In short, culturally-blind policy programs that classify the policy objects only according to social class and status will fail to fulfill their goals. It is possible that some politicians might attain certain positive outcomes in the short term by appl ying such policy programs. However, these gains would not represent the achievement of real, sustainable breakthroughs in long-term community development and the alleviation of poverty. Instead, appropriate and sustainable economic policymaking takes local political-culture background into account, as illustrated in the subsection below.

\section{Advancing Disadvantaged Urban Communities: APolicy Framework}

The most basic policy scheme assumes the existence of several analytical stages in the policymaking process: problem definition, setting alternatives, formulating strategies, and designing policy programs (Hague \& Harrop, 2013, Patton et al., 2015). The guiding principle highlighted by the political-culture approach is that, in order to enhance policy effectiveness and to control policy outcomes, policymakers must synchronize those abstract, universalistic procedures with local culture-based knowledge (Geva-May, 2002, Hoppe, 2002, Froggett \& Chamberlayne, 2004, Easterly et al., 2006; Reese \& Rosenfeld, 2008, Woolcock et al., 2010, Grodach, 2012, Dahan, 2016 \& 2017). The fact that different communities have varied cultural modes and differing organizational resources suggests that policymakers should identify and conceptualize the particular attributes of each community under consideration as a prerequisite for effective choice, adjustment and use of certain strategies and instruments. In light of the above, it is possible to create a schematic outline for synchronizing these various parameters (general and local) to provide a methodological framework that

${ }^{2}$ Local history is, by its very nature, bound to and embedded in political culture. In practice, culture is shaped by collective memory, formed and conserved within "cultural schemas" (see: Strauss \& Quinn, 1997). For example, if a political "culture of distrust" exists, it often follows from a "history of distrust" (Bockmeyer, 2000). As such, Woolcock et al., (2010) argue that policy failure also stems from the "absence of a serious historical sensibility among de velopment policy administrators"(2010:14).

${ }^{3}$ According to Wildavski's typology (1987), a fatalistic (or apathetic) society is defined as having weak group boundaries ("low group") combined with a high level of prescriptions (high grid). 
facilitates the constructive and efficient management of policy craft, as illustrated in Table 1 below.

Table 1. Policy-process management based on political-culture: a methodological framework

\begin{tabular}{ll}
\hline & General policy goal: Urban economic \\
\hline Political Culture & ProblemDefinition \\
\hline Category A & Internal differences in social and \\
& human capital. \\
Non-cohesive and highly & $\begin{array}{l}\text { No circulation of social capital. } \\
\text { segregated community. }\end{array}$ \\
Misinterpretation of policy \\
program.
\end{tabular}
helfare Strategies and Policy Programs

A differential policy program that fits the needs of specific communities (e.g., supporting communities which share a low level of social capital). program.

Removing barriers in order to circulate social capital (e.g., supporting and funding committed community-based organizations)

Pro-active intervention through state institutions to mainta in "social contracts" as prerequisites for applying reforms.

Category $B \quad$ Weak economic performance of Avoiding decentralization and tightening regulation Community dominated by local organizations (municipality, enforcement; pro-active intervention in rebuilding urban nepotism.

A low level of human capital and coalitions, by funding community-based organizations committed to act according to professional guidelines. selective emigration ("brain drain" of human capital).

Category $C$ towards local elite (vertical distrust).
Individuals and local businesses are less likely to take part in a new economic order.

Low level of bridging social capital.

Low level of exctracting rights.

Governmental intervention on behalf of local businesses in order to remove barriers (rooted in distrust), such as providing financial guarantees.

Governmental intervention in building institutions that maintain and support vertical interactions or restructuring, e.g., promoting interaction with local elites and local leadership.

Supporting community-based organizations that act in order to inform civilians of their rights.

\begin{tabular}{ll}
\hline $\begin{array}{l}\text { Category D } \\
\text { Patriarchal-hierarchical society. }\end{array}$ & $\begin{array}{l}\text { Tight, internal hierarchy that Granting financial assistance to culturally-sensitive } \\
\text { excludes large parts of the employers, who adjust the ir work environment to suit the } \\
\text { population from the labor market local political culture. }\end{array}$
\end{tabular}
(e.g., women)

The goal of the policy process presented above in Table 1 centers on urban economic growth and improved community welfare, targeting the welfare of relatively poor communities - a common strategy of many governments in western countries (Logan \& Molotch, 2007). It is clear, in light of the previous detailed discussions, that applying such policy programs without taking into account cultural differentiation would probably cause the differential utilization of resources, which would likely perpetuate socio-economic inequality. In order to achieve a breakthrough, policymaking experts should first identify the political-culture patterns of the communities under discussion. Table 1 presents four hypothetical types of political culture, or social orders. The common thread running through the columns labelled "Problem Definition" and "Strategies and Policy Programs" is that identification of the type of political culture redefines the policy problem. This, in turn, leads to the formulation of different strategies and more effective use of policy levers.

The first category (A) refers to a non-cohesive and highly-segregated society. Since, in such societies, various communities share a low level of interaction between subgroups, it is less likely to encounter a high level of social capital . Hence, policy intervention should be implemented in order to promote the circulation of social capital (Woolcock, 2001). Examples include supporting locally-based organizations that sponsor cross-cultural activities, or modifying land-use plans to improve interactions between different subgroups. A better way to deal with this cultural pattern is by a differential distribution of resources (financial and organizational). Diversity is best handled by focusing on communities that share a low level of social capital and supporting them by means of initiatives, for instance, by establishing a nearby employment office in the vicinity.

A non-cohesive and highly segregated society has additional problems that stem deeper. Easterly et al. (2006) note that such segregation may become an obstacle for policymakers because success in applying economic-policy reform

\footnotetext{
${ }^{4}$ Taking such a strategic stance may be relevant to immigrant societies comprised of an extremely diverse mixture of ethnic groups in terms of human and social capital. The most conventional policy applied in immigrant societies is generally based on the principle that the best way to enable newcomers to adjust to their new environment is either by giving them financial support or by subsidizing their activities. However, such a uni versal policy may not be effective if that society is characterized by internal diversity in political culture, which impacts the economy and social welfare. As Logan and Molotch demonstrate (2007), different groups of immigrants in the United States who are usually identified by their common ethnic origin (e.g., Jews, Italians, Hispanics, etc.) share different levels of solidarity (social capital).
} 
eventually depends on a "social contract," a common, unwritten platform from which various groups and subgroups, as well as the local elite and local leadership, draw support and use to justify their preferences and decisions. Non-cohesive societies often lack this crucial, unifying element. Hence, a sustainable intervention is one that strives to create and sustain a social contract. Easterly et al. (2006) suggest that an effective way to do so is via the public education system, in which states can provide citizens with general knowledge regarding social contracts between individuals and between individuals and the state, thus equipping students with the tools to understand what happens if the social contract is violated.

The second political-culture category (B) refers to a community dominated by nepotism, namely a society in which the social, political and economic order is shaped by the local elite, who redistribute public resources and public goods in favor of their relatives and friends. Naturally, this kind of political order has significant implications for any local economy: the appointment of officials and allocation of resources using unprofessional criteria lead to the weak economic performance of the local municipal agencies (in cases in which the community under discussion enjoys municipal autonomy). Under such cultural conditions, the better-educated residents of these communities often emigrate (an example of brain drain of human capital). Given this circumstance, it is clear that policy intervention should not promote or initiate political decentralization, which would intensify the existing dynamics. Instead, governments above the municipal level should consider tightening regulations and increasing oversight to reduce these negative trends. In such cases, governmental intervention should aim to promote changes in cultural orientation. This can be accomplished, for example, by taking a pro-active stand supporting an inclusive and egalitarian urban coalition. Such initiatives may be aided by means of financial support or by the enactment of special regulations that favor non-governmental organizations promoting inclusivity and egalitarianism.

The third political-culture category (C) refers to communities in which members have a high degree of distrust of the political establishment on the state or metropolitan levels (vertical distrust). As noted, such cultural patterns have severe negative implications for urban economy and community welfare. Distrusting the political establishment means that even when the government or its officials honestly initiate and push forward an urban economic plan that might benefit the community, it is likely that the community members will miss the proffered economic benefits and opportunities embodied in that plan. For instance, it is possible that even resident entrepreneurs will not take active steps to take advantage of the new order; they may neglect to prepare and reorganize - logistically and financially —in order to serve the increasing demand that may arise from the expected urban growth. Governmental intervention may overcome such barriers (termed "market failure" by economists), by providing go vernment-backed financial guarantees to individuals or locally-based organizations that do step up and take appropriate action. A political culture of distrust also suggests a potential loss of bridging social capital. Due to the relatively poor interaction between urban communities and high-level social milieu (e.g., the greater metropolitan political elite), there are few institutions that rely on vertical social interaction. As a result, ordinary community members interact less often with the higher echelons. This sociological structure maintains a dynamic in which social capital stays on the local, horizontal level (namely bonding social capital), which is essentially limited, as previously noted, in terms of its potential economic benefits. Hence, a governmental intervention should focus on altering this situation by discovering or creating new channels to bridge the gaps and encourage the circulation of social capital. Logan and Molotch reveal (2007:42-139) that a policy orientation that strove to achieve dialogue and a common basis with the local leadership in Chicago's poor neighborhoods made a significant difference. The guiding concept is that local elite groups and local leadership have added value due to their being raised in the community as in-group members. Simultaneously, as elites and relatively well-educated people, they often share common experiences with colleagues on the wider metropolitan level, although they may come from different sociological contexts and backgrounds (e.g., time spent together in the university). Therefore, any policy intervention should focus on the local elite group as an effective means for breaking out of the vicious cycle of distrust, potentially leading to an eventual enriched bridging of social capital (see also: Dahan, 2017).

The fourth political-culture category (D) refers to a society dominated by a religious, hierarchical-patriarchal base - a sociological pattern that is common in immigrant neighborhoods, populated by traditional, ethnic minorities. This type of political culture often strongly discourages women from participating in the labor market, the negative impact of which is felt in local welfare conditions, manifested by a relatively high unemployment rate and low economic growth rate. Unlike the above patterns of socio-cultural order (A, B, and C), it is unlikely in this case (D) that the neighborhood leaders and local elite will take action to change such an economic order (i.e., go against their traditional beliefs). Thus, a policy intervention that aims at modifying their customary lifestyle will likely be untenable and fruitless. Nevertheless, governments that aim to reduce poverty and improve local economy, while minimizing potential culture conflict with the local elite, may successfully meet such challenges by adopting policy programs that "create flexible boundaries" (Buchbinder et al., 2015:395). In practice, this goal is achievable, for instance, by granting financial incentives to those employers who adapt the physical environments of their workplaces to local cultural requirements, perhaps by providing gender segregation in the workplace. 


\section{Summary and Conclusions}

The primary goal of this study was to broadly examine recently published studies on the political-culture approach in the urban arena to better understand the qualities of urban community economics and public welfare, as well as their implications on policymaking. This review has demonstrated that the practical application of the political-culture approach may serve as a valuable resource of knowledge towards a better understanding of local economy and community socioeconomic welfare. A political-culture analysis emphasizes the need to reorganize and refresh the theoretical framework and methodology in such a way that both differentiates and integrates rational-economic logic with cultural awareness and sensitivity; it also demonstrates the need to combine the material resources with the abstract resources, as well as to integrate the macro and micro contexts.

To an extent, this approach aligns with certain grand integrationist and holistic theories for understanding social constructs (Giddens, 1984) that inevitably challenge existing theories and schools of thought. The fact that urban economy is also shaped by shared values, collective memory, norms, etc., sheds critical light on the political economy approach, which rests on "a pervasive assumption based on a conviction that all elements within the community respond primarily to opportunities for material gain, as well as imminent threats to their economic interests" (Rosdil, 2011:3).

Beyond theoretical dimensions, the primary thrust of political-culture studies has significant implications on analytical and practical policymaking. As shown above, the frequent failure of many policy programs stems from a pervasive orientation among policymakers to utilize pre-existing, culturally-blind policy programs. Recent theoretical innovations in the urban subfield, following macro-structural trends and strategies (e.g., "pro-growth economy," "regime theory," "creative city" or even "economic base theory") may prove valuable for analyzing and advancing contemporary urban economy. However, the fact that various urban communities interpret these new trends and strategies differentially in accordance with their local histories, hierarchies and resources means that it is necessary to take these inputs into account in order to achieve successful policy outcomes, integrating them into any model for formulation to advance urban community. Table 1, presented above, may serve as a practical tool for achieving such goals.

\section{References}

Almond, G. (1990). A Discipline Divided: Schools and Sects in Political Science. Ch.5: The study of political culture, 38-155. Newbury Park: SAGE.

Andrews, R. (2009). Civic engagement, ethnic heterogeneity, and social capital in urban areas: Evidence from England. Urban Affairs Review, 44(3), 428-440. https://doi.org/10.1177/1078087408321492

Banfield, E. C. (1967). The Moral Basis of a Backward Society. Glencoe: Free Press.

Bockmeyer, J. L. (2000). A culture of distrust: The impact of local political culture on participation in the Detroit EZ. Urban Studies, 37(13), 2417-2440. https://doi.org/10.1080/00420980020080621

Buchbinder, E., Sigad, L., Strier, R., \& Eisikovits, Z. (2015). Working poor ultra-Orthodox Jewish women and men: Between economic distress and meaning based on faith. Journal of Poverty, 19(4), 377-398. https://doi.org/10.1080/10875549.2014.999971

Burgess, E. (1961). The growth of the city: An introduction to research projects. In: G. A. Theodorson (Ed.). Studies in Human Ecology, 37-44. Evanston: Row, Patterson.

Castells, M. (1977). The Urban Question: A Marxist Approach. London: Edward Arnold.

Dahan, Y. (2016). University, community, identity: Ben-Gurion University and the city of Beersheba: a political-culture analysis. Israel Affairs, 22(1), 189-210. https://doi.org/10.1080/13537121.2015.1111631

Dahan, Y. (2017). Urban distress and political narrative: Life stories of local leaders in a poor, underprivileged suburb and the reconstruction of urban order. Qualitative Social Work, 16(2), 255-272. https://doi.org/10.1177/1473325016658113

Easterly, W., Ritzen, J., \& Woolcock, M. (2006). Social cohesion, institutions, and growth. Economics \& Politics, 18(2), 103-120. https://doi.org/10.1111/j.1468-0343.2006.00165.x

Froggett, L., \& Chamberlayne, P. (2004). Narratives of social enterprise: From biography to practice and policy critique. Qualitative Social Work, 3(1), 61-77. https://doi.org/10.1177/1473325004041132

Fukuyama, F. (2000). Social capital. In: L. E. Harrison, and S. P. Huntington, Culture Matters, pp. 98-111. New York: Basic Books.

Geva-May, I. (2002). Cultural theory: The neglected variable in the craft of policy analysis. Journal of Comparative Policy Analysis: Research and Practice, 4(3), 243-265. https://doi.org/10.1080/13876980208412682 
Giddens, A. (1984). The Constitution of Society: Outline of the Theory of Structuration. Berkeley: University of California Press.

Grodach, C. (2012). Before and after the creative city: The politics of urban cultural policy in Austin, Texas. Journal of Urban Affairs, 34(1), 81-97. https://doi.org/10.1111/j.1467-9906.2011.00574.x

Grondona, M. (2000). A Cultural Typology of Economic Development, p. 46. In: Lawrence E. Harrison, and Samuel P. Huntington (Eds.). Culture Matters: How Values Shape Human Progress. New York: Basic Books.

Hague, R., \& Harrop, M. (2013). Comparative Government and Politics: An Introduction. Ch. 18, pp. 378-394. London: Palgrave Macmillan.

Harvey, D. (1973). Social Justice and the City. London, Edward Arnold.

Hoppe, R. (2002). Cultural theory's gift for policy analysis. Journal of Comparative Policy Analysis: Research and Practice, 4, 235-240. https://doi.org/10.1080/13876980208412681

Horrigmo, A. M. J. (2013). Can culture explain culture? The influence of cultural change on municipal spending on cultural policies. Urban Affairs Review, 49(3), 408-434. https://doi.org/10.1177/1078087412461241

Landes, D. (2000). Culture makes almost all the difference, pp. 2-13. In: Lawrence E. Harrison, and Samuel P. Huntington (Eds.). Culture Matters: How Values Shape Human Progress. New York: Basic Books.

Lane, R. (1992). Political culture: Residual category or general theory? Comparative Political Studies, 25(3), 362-387. https://doi.org/10.1177/0010414092025003004

Logan, J. R., \& Molotch, H. (2007). Urban Fortunes: The Political Economy of Place. Berkeley: University of California Press. 20th Anniversary edition.

Middleton, A., Murie, A., \& Groves, R. (2005). Social capital and neighborhoods that work. Urban Studies, 42(10), 1711-1738. https://doi.org/10.1080/00420980500231589

Patton, C., Sawicki, D., \& Clark, J. (2015). Basic Methods of Policy Analysis and Planning. Routledge.

Porter, M. E. (2000). Attitudes, values, beliefs, and the microeconomics of prosperity, pp.14-28. In: Lawrence E. Harrison, and Samuel P. Huntington (eds.). Culture Matters: How Values Shape Human Progress. New York: Basic Books.

Putnam, R. D. (1993). Making Democracy Work. Princeton: Princeton University Press.

Putnam, R. D. (2001). Bowling Alone: The Collapse and Revival of American Community. New York: Simon and Schuster.

Quentin D., Janiak, A., \& Wasmer, E. (2010). Local social capital and geographical mobility. Journal of Urban Economics, 68(2), 191-204. https://doi.org/10.1016/j.jue.2010.04.003

Reese, L. A., \& Cox, D. S. (2007). Local culture and governmental change: The endurance of culture in the face of structural change. Canadian Public Administration, 50(2), 245-271. https://doi.org/10.1111/j.1754-7121.2007.tb02012.x

Reese, L. A., \& Rosenfeld, R. A. (2008). Introduction: Comparative civic culture. Journal of Urban Affairs, 30(4), 355-374. https://doi.org/10.1111/j.1467-9906.2008.00404.x

Rosdil, D. (2010). Testing cultural and economic explanations for local development policies: The competing claims of security, distress, and nontraditional subcultures. Journal of Urban Affairs, 32(1), 105-130. https://doi.org/10.1111/j.1467-9906.2009.00477.x

Rosdil, D. (2011). Civic culture, sub-cultures, non-traditionalism and progressive policy: Using value change to explain new US development strategies in the 21 st century. Urban Studies, 48(16), 3467-3486. https://doi.org/10.1177/0042098010396236

Sachs, J. (2000). Notes on a new sociology of economic development, pp. 29-43. In:Lawrence E. Harrison, and Samuel P. Huntington (eds.). Culture Matters: How Values Shape Human Progress. New York: Basic Books.

Savitch, H. V., Kantor, P., \& Vicari, S. H. (2002). Cities in the international marketplace: The political economy of urban development in North America and Western Europe. Princeton University Press.

Stone, C. N. (1989). Regime Politics: Governing Atlanta, 1946-1988. Lawrence: University Press of Kansas.

Stone, C. N. (1993). Urban regimes and the capacity to govern: A political economy approach. Journal of Urban Affairs, 15(1), 1-28. https://doi.org/10.1111/j.1467-9906.1993.tb00300.x

Strauss, C., \& Quinn, N. (1997). A Cognitive Theory of Cultural Meaning, 9. Cambridge: Cambridge University Press. 
Thompson, M., Ellis, R., \& Wildavski, A. (1990). Cultural Theory. Boulder: Westview Press.

Wildavsky, A. (1987). Choosing preferences by constructing institutions: A cultural theory of preference formation. American Political Science Review, 81(1), 3-21. https://doi.org/10.2307/1960776

Woolcock, M. (2001). The place of social capital in understanding social and economic outcomes. Canadian Journal of Policy Research, 2(1), 11-17.

http://citeseerx.ist.psu.edu/viewdoc/download;jsessionid=C6929EF06AFBF0F984877E8D07025252?doi=10.1.1.4 63.2107\&rep=rep1\&type $=$ pdf

Woolcock, M., Sertzer, S., \& Rao, V. (2010). How and Why Does History Matter for Development Policy? Washington, DC: World Bank. https://doi.org/10.1596/1813-9450-5425

\section{Copyrights}

Copyright for this article is retained by the author(s), with first publication rights granted to the journal.

This is an open-access article distributed under the terms and conditions of the Creative Commons Attribution license which permits unrestricted use, distribution, and reproduction in any medium, provided the original work is properly cited. 